\title{
Evaluation of Deterioration and Proposed Restoration of the Limestone, White Monastery-Sohag, Egypt
}

\author{
Abd-Elkareem E. Ahmed1*, Ahmed 0. Mashaly², Basel N. Shalaby², Mohamed A. Rashwan² \\ ${ }^{1}$ Conservation Department, Faculty of Archaeology, South Valley University, Qena, Egypt \\ ${ }^{2}$ Geology Department, National Research Center, Cairo, Egypt \\ Email: *elashmawyabdelkareem@yahoo.com
}

How to cite this paper: Ahmed, A.-E.E., Mashaly, A.O., Shalaby, B.N. and Rashwan, M.A. (2017) Evaluation of Deterioration and Proposed Restoration of the Limestone, White Monastery-Sohag, Egypt. Open Journal of Geology, 7, 1287-1302.

https://doi.org/10.4236/ojg.2017.79085

Received: July 31, 2017

Accepted: August 29, 2017

Published: September 1, 2017

Copyright $\odot 2017$ by authors and Scientific Research Publishing Inc. This work is licensed under the Creative Commons Attribution International License (CC BY 4.0).

http://creativecommons.org/licenses/by/4.0/

\begin{abstract}
By studying the phenomena of limestone built from the White Monastery in Sohag Governorate damage where this study discusses the results of the analyzes and the study's petrographic limestone, we can study and discuss what has been done to analyze X-ray diffraction and X-ray flourecence, and by scanning electron microscope in order to determine the cause of the damage and to study the properties of limestone to choose the most appropriate treatment methods especially the internal structure affected by the environmental conditions surrounding the private and increasing ground water levels along with the use of the most appropriate ways to buffer water to conserve the limestone of the environmental factors that damage it.
\end{abstract}

\section{Keywords}

White Monastery, Limestone, Deterioration, Preservation, Sealers

\section{Introduction}

The famous White Monastery Archimandrite is located near Sohag city in Upper Egypt (Figure 1). It covers an area about 12,800 acres and contains several churches and buildings attached to private services and outbuildings, where there are kitchens, warehouses and rooms for resident monks. White monastery church is the most famous ancient Egyptian church and called after the monastery's name [1]. The monastery has been built from limestone from the nearby area quarries [2] [3]. The church in the white monastery has a rectangular shape with dimensions of $(74.85 \mathrm{~m} \times 37 \mathrm{~m})$. The four walls of the church are built from limestone, the western, northern and southern walls have two entrances and two rows of 


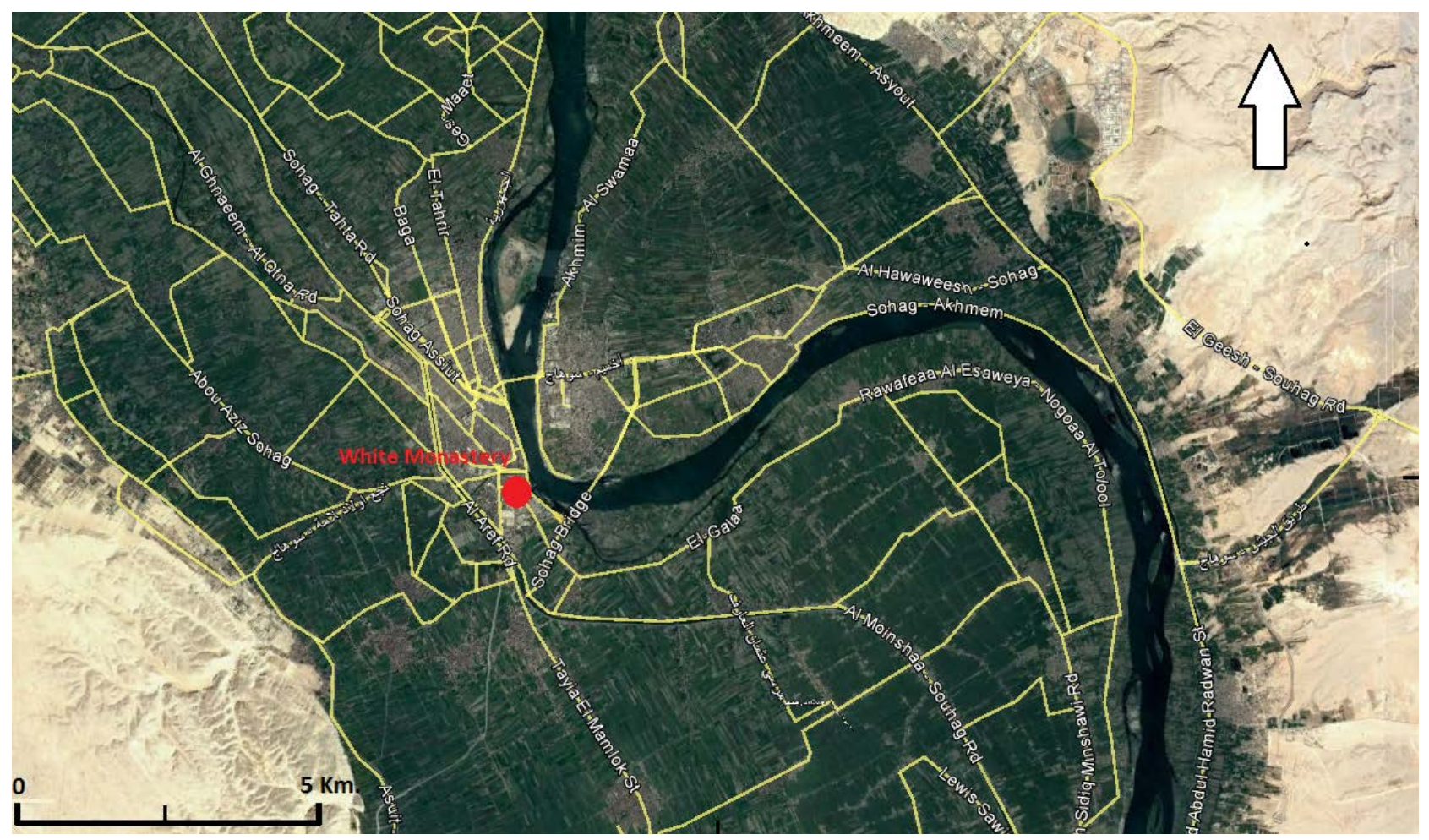

Figure 1. Site area of the white monastery, Sohag, google 2016.

windows, walls have been built sloping towards inside, resembling the walls of Pharaonic temples and the system bearing walls [4]. The building planning of this church shows a lot of ambiguity about its history, where it is observed that the overall planning of a basilica with three galleries, and structure of the three-apses belongs to the fourth and seventh centuries $\mathrm{AD}$, and the architectural elements such as Corinthian columns are closely related to those that have spread in the Byzantine era [5] [6] [7].

\subsection{Aim of the Present Study}

The present work aims to study the deterioration phenomena in White monastery walls and blocks and to propose the suitable methods of restoration.

\subsection{Deterioration of Limestone of White Monastery Monument Stones}

Historically stone masons have been worked with different stone materials as limestone, which was primarily used in building massive structures, to sand stones, clays, granite and marble which were more commonly found in statues and monuments. Since prehistoric times, and up till now, limestone is considered to be one of the widely common types of building stone, and in conservation practice as a replacement material for the reconstruction of monuments.

Calcite represents the main mineral constituent of the limestone, but the minor mineral constituents as well as structures and textures may result in a complicated weathering behaviour. 
The ICOMOS-ISCS [8] defined deterioration as the "process of making or becoming worse or lower in quality, value, character, etc." and decay as "any chemical or physical modification of the intrinsic stone properties leading to a loss of value or to the impairment of use". Degradation is defined as the "decline in condition, quality, or functional capacity". Weathering is generally defined as "any chemical or mechanical process by which stones exposed to the weather undergo changes in character and deteriorate" [9].

The White Monastery limestone bricks and walls have been affected by several weathering factors, all together controlled the type and extent of stone decay, [10]. The observed stone deterioration phenomena were:

1) Stone material fatigue: occurs as a result of temperature changes between day-night, as well as seasons, leading to volume changes expressed as expansion and shrinking, the continuous temperature change causes cracks and fractures on stones as a result of the material fatigue [11] (Figure 2).

2) Internal disintegration: expressed as powdering of the stone behind the skin (surface crust), as a result of breaking down of the internal structure of the rock. This may be due to retention of fluids which are not allowed to escape by normal evaporation due to the impermeable nature of the skin. Some sets of cracks are noticed developed parallel to the exposed stone surface, and the internal structure is effectively shattered (Figure 3).

3) Efflorescence: soluble salts are considered to be the main cause of stone decomposition. Salts are usually cause stone damage in several ways. The most common is the growth of salt crystals in the stone pores, resulting in stresses that may overcome the stone's tensile strength [12] [13] [14] [15]. The efflorescence action may proceed as long as the soluble salts remain in the stone, by time, the

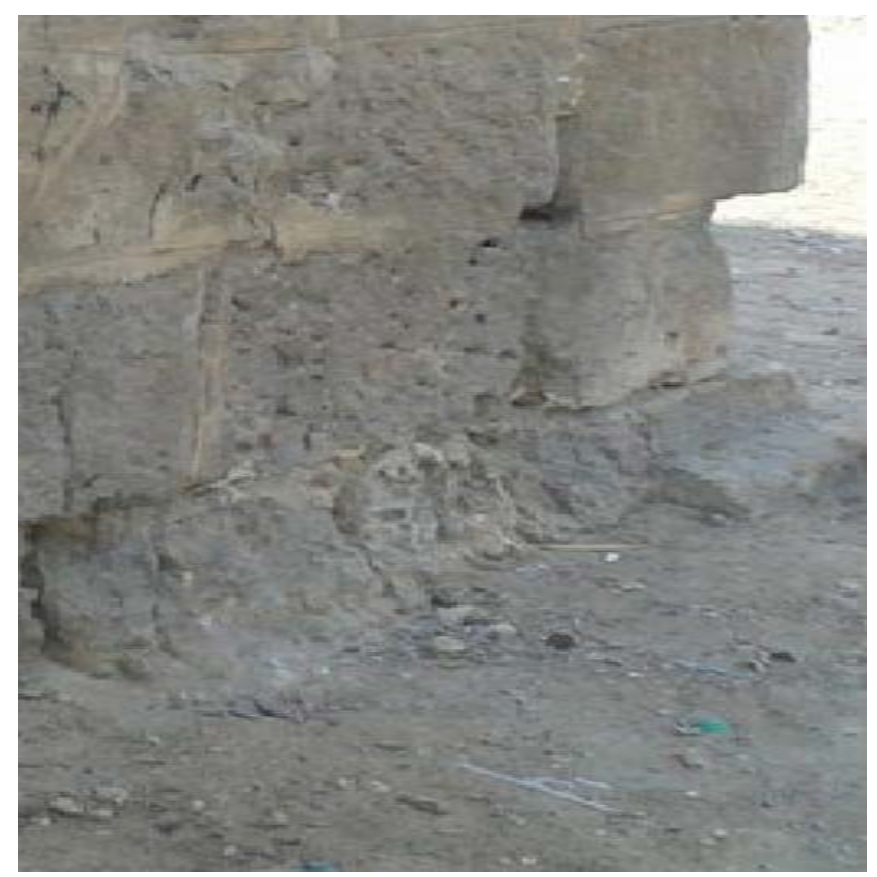

Figure 2. Stone material fatigue in. 


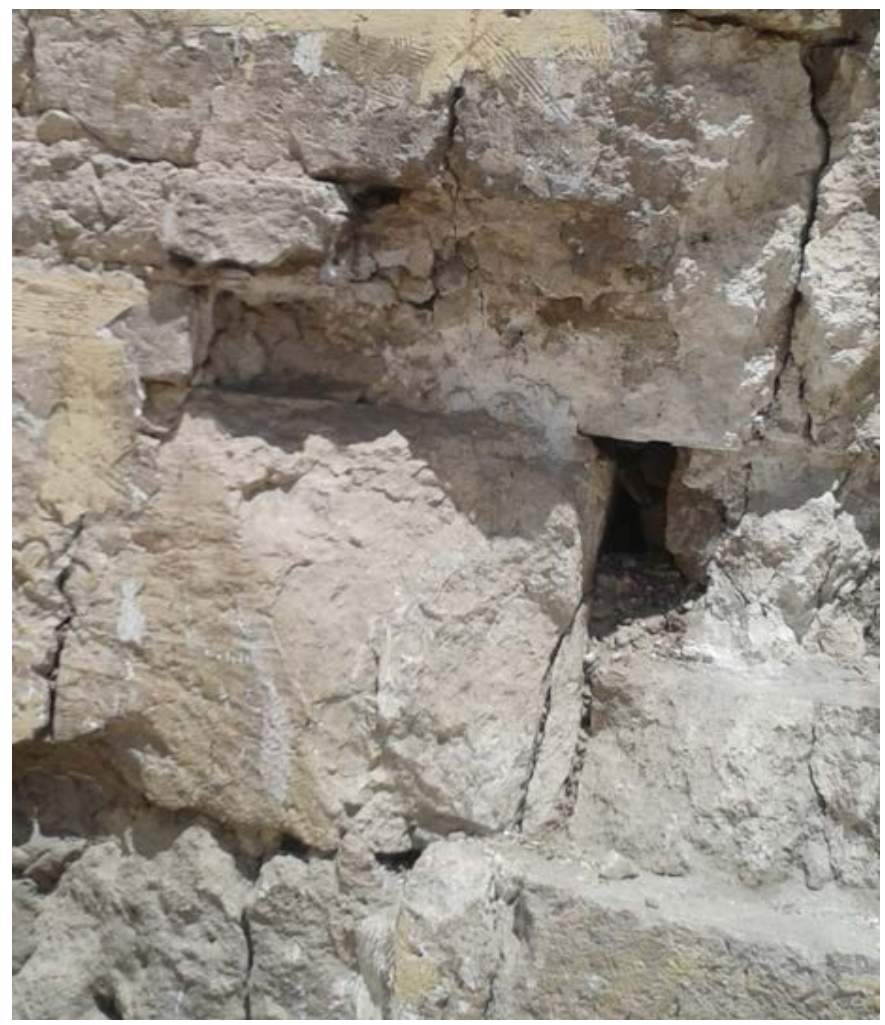

Figure 3. Internal disintegration.

soluble salts dissolved in the fluids are concentrated, and on crystallization, the crystallized salts initiate the disintegration.. The soluble salts may, also crystallize on the stone surface forming unsightly deposits, known as "efflorescence". The effect of salt deterioration is expressed on the limestone of the walls as shown in Figures 4-6.

4) Crust removal: the temperature change produces stresses resulted from the differential expansion, such stresses tend to cause delamination of the surface. When the wet stone surface warms by long exposure to the sun, as well as warm atmosphere, the surface expands and, contemporaneously, evaporation-precipitation processes takes place. Calcium sulphate crystals may be deposited in the fine cracks developed during the expansion phase. The repetition of these processes may produce an observed expansion and/or blistering of the crust (surface layers) (Figure 7).

5) Biodeterioration: the biologic activities of bacteria and algae, negatively, affect the stone mechanically and chemically, Mechanical damage is caused by penetration of the hyphae into the stone and by the expansion and contraction of the thallus (the vegetative part of the fungus) under changes of humidity. Chemical damage [16], however, is more important and may arise in three ways: by the secretion of oxalic acid, by the generation of carbonic acid, and by the generation of other acids capable of chelating ions such as calcium [17]. The limestone of the walls shows borrowings and detachments due to biodeteriorations (Figure 8). 


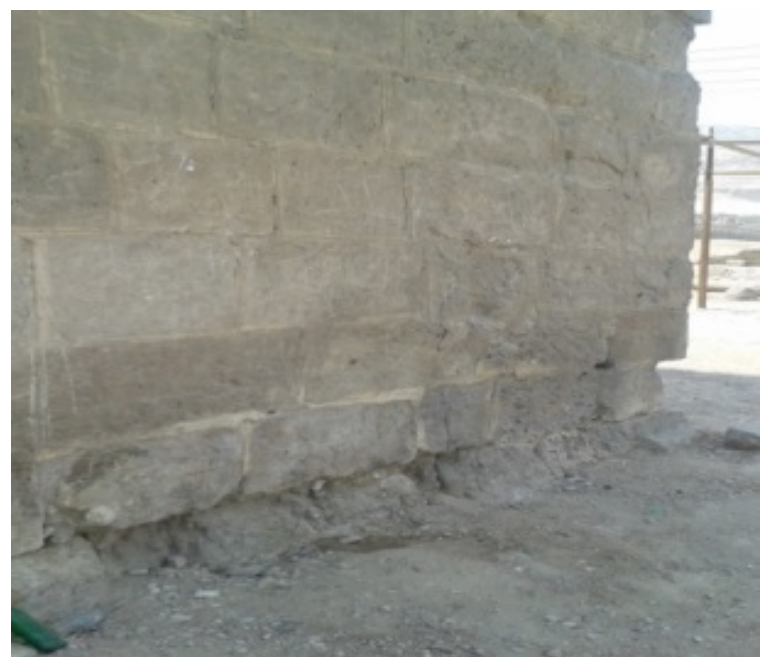

Figure 4. Continuous deterioration action resulted from efflorescence and salt crystallization.

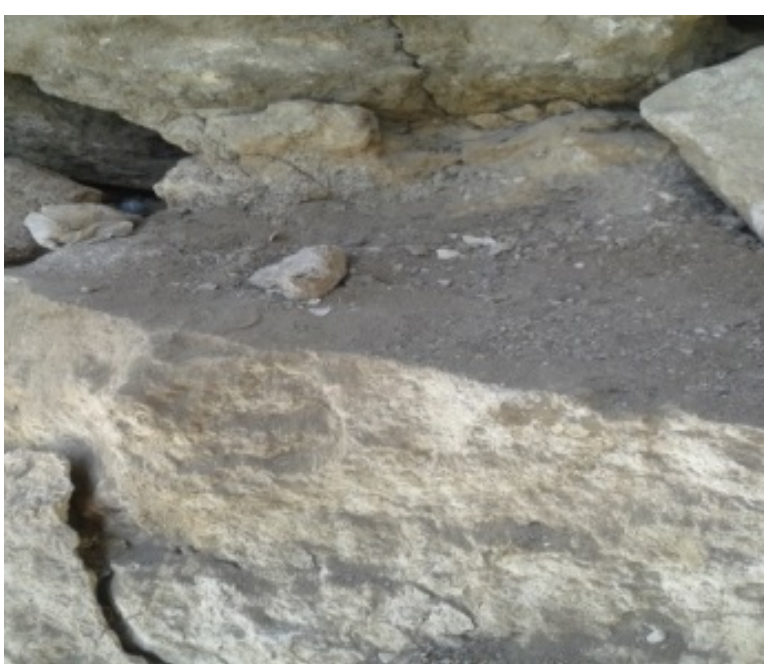

Figure 5. Foundations affected by ground water.

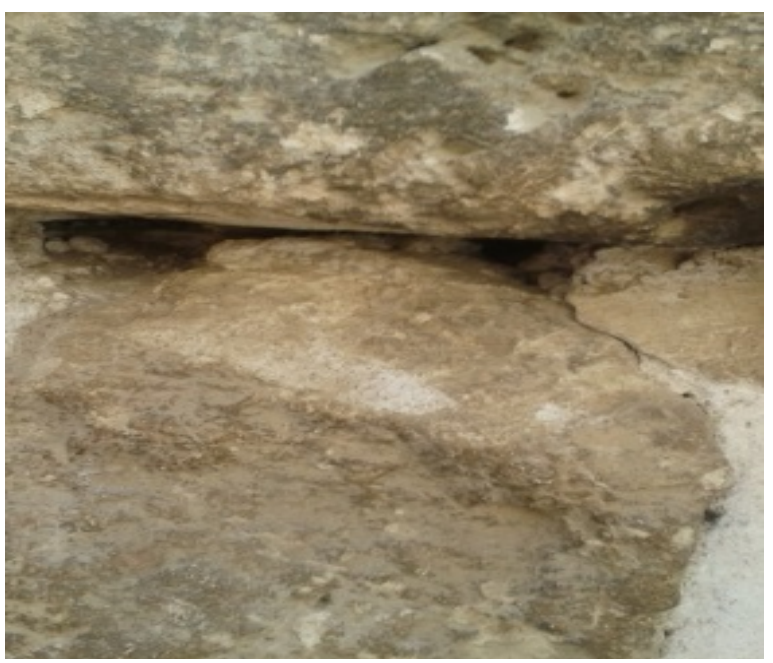

Figure 6. Detachment and salt crust on limestone surface. 


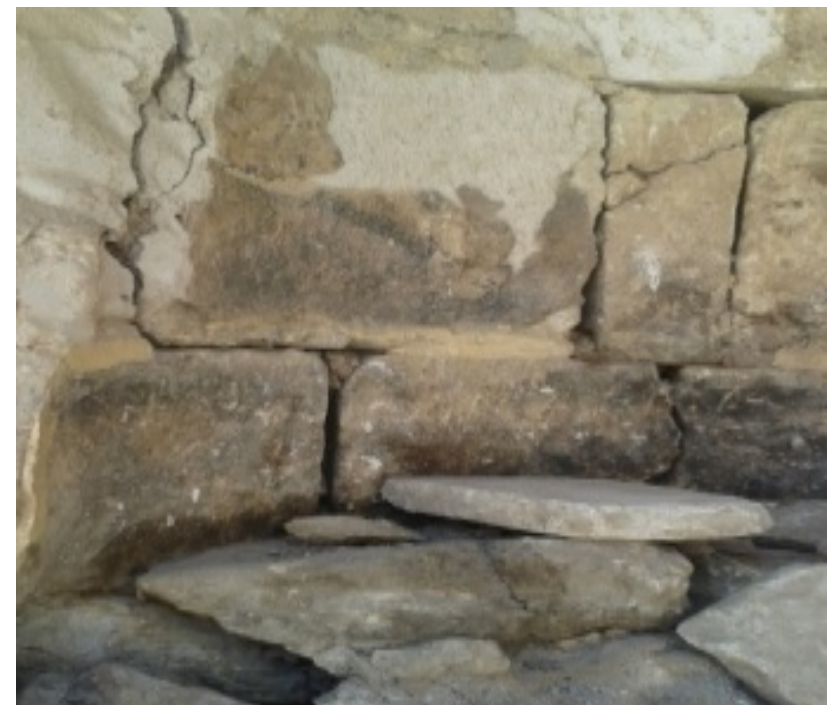

Figure 7. Loosening of stone crust.

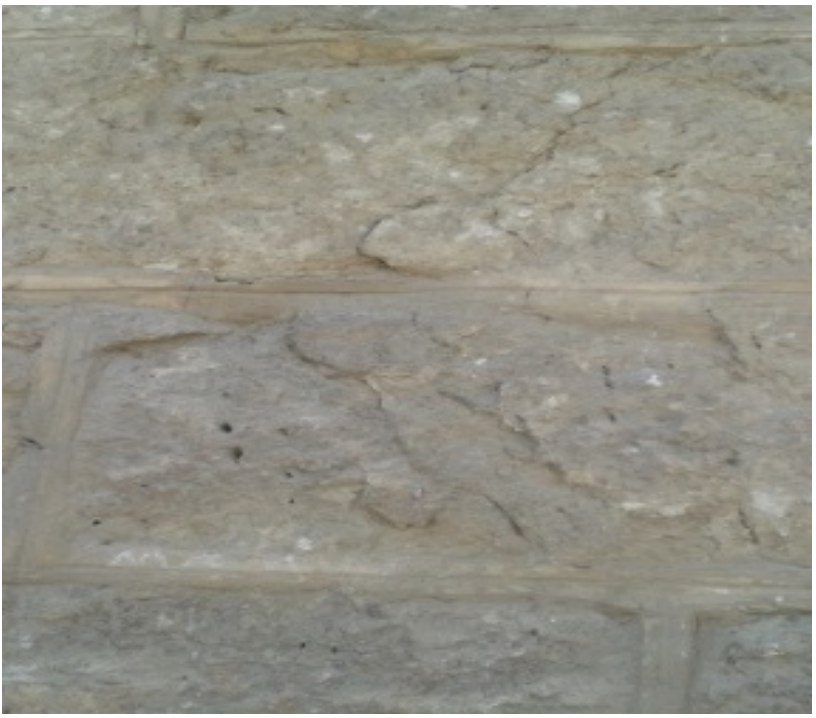

Figure 8. Effect of borrowing on limestone.

\section{Materials and Methods}

The nature of the limestone used in the construction of white monastery is studied and the nondestructive samples were collect to show its ability to deteriorate and to propose the suitable restoration procedures, Petrographic using Nikon polarizing microscope, scanning electron microscope using JEOL JSM5500LV, south valley University, Egypt, XRD analysis (using Philips diffractometer, $\mathrm{Cu} \mathrm{K}$ radiation of 2 - 60 degrees, Department of Physics, Assiut University, Egypt). And chemical analysis methods were performed using (Axios advanced, sequential wd_XRF Spectrometer, PANalytical 2005) at the analysis and consulting unit, National Research Center in Cairo. The physical and mechanical properties of the limestone samples were also studied in lab of building materials properties, National Research Center in Cairo. 


\section{Results and Discussion}

\subsection{Petrographic Examination}

The studied limestones are Nummuliticbiomicrites and represented by a varying amount of fossils and fossil fragments embedded in a micritic matrix (Figure 9 and Figure 10). Allochems consists mainly of different types of foraminifera (Nummulites is the most dominant type). Nummulites content ranges between $20 \%-30 \%$ by volume, the other bioclasics form about $10 \%$ and represented, mainly, by randomly oriented algal remnants and fossil fragments (Figure 11). Most of fossils were, partially, replaced by sparry calcite, while lesser amounts of fossils were partially recrystallized and others were subjected to partial dissolution, in their cores. The inner cores of Nummulites are filled with micritic and/or sparritic calcite (Figure 12). The allochems embedded in the matrix are composed mainly of micrite. The micritic matrix shows slight neomorphism into microsparite. Terrigenous material (mainly fine detrital quartz) occurs scattered in the micritic matrix.

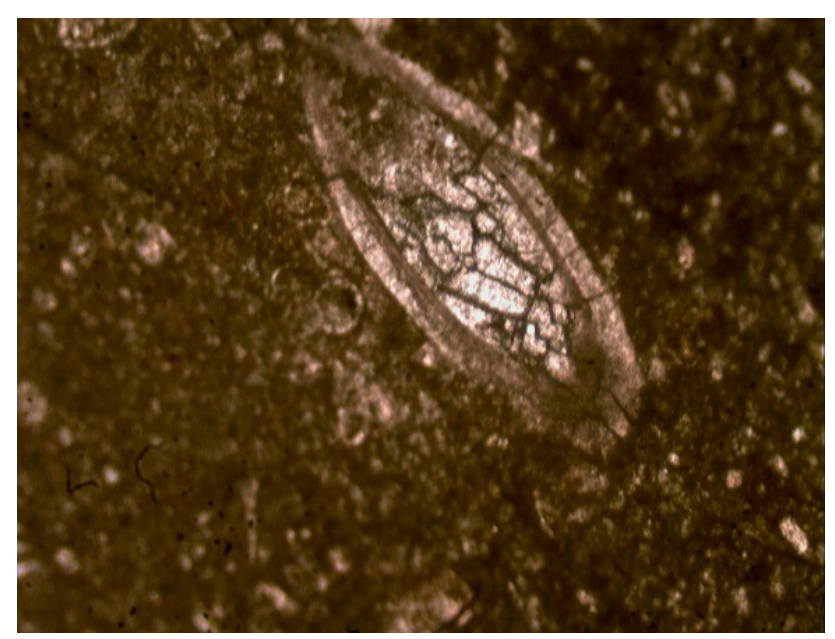

Figure 9. Fossil embedded in micrite.

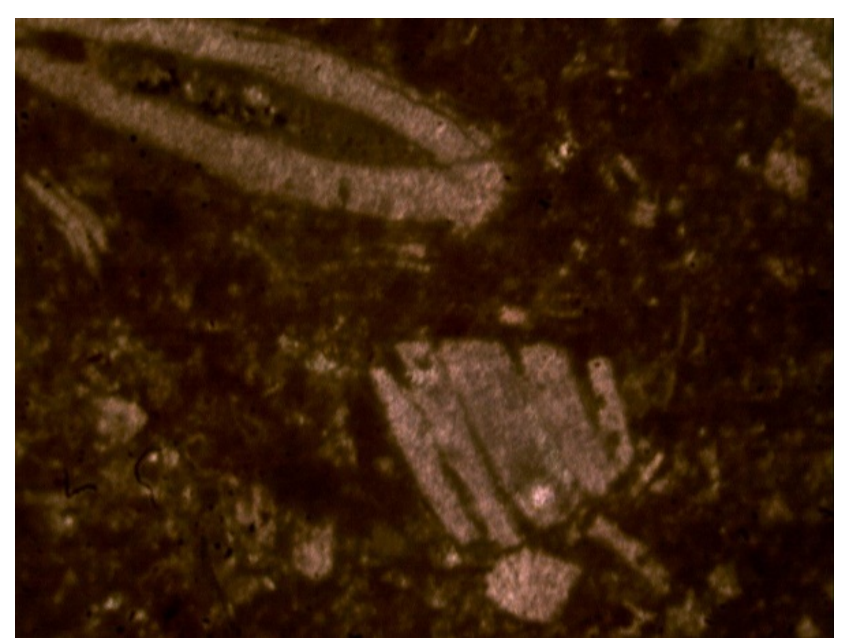

Figure 10. Fossils and fossil fragments. 


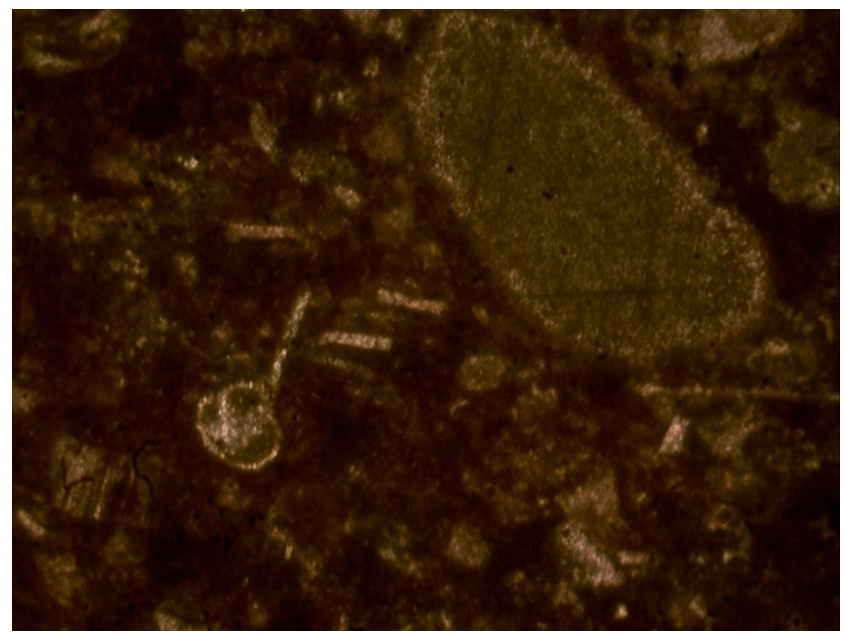

Figure 11. Fossils and algae.

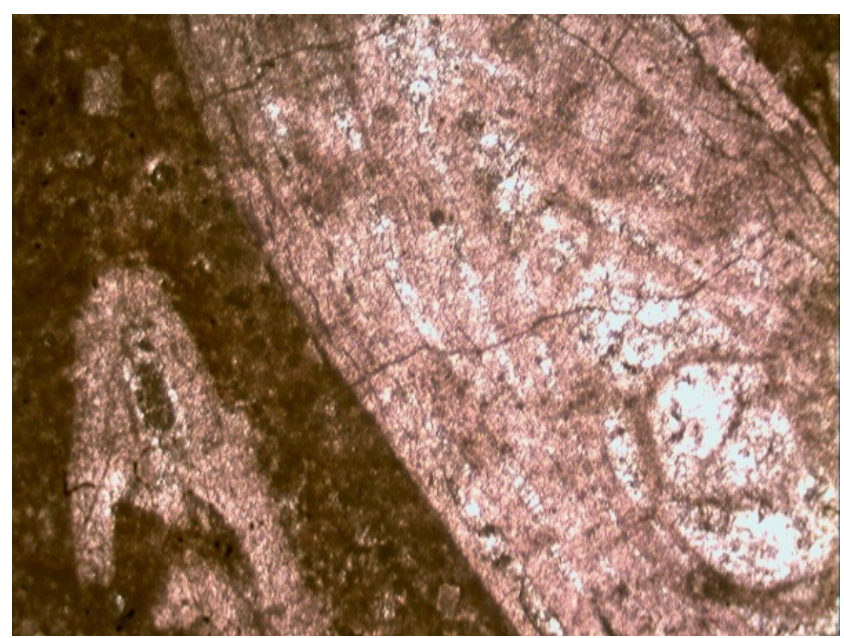

Figure 12. Fossil filled with sparry calcite.

\subsection{Scanning Electron Microscope Study (SEM)}

The study of the limestone samples with the scanning microscope show the presence of micropores and microcracks (Figure 13 and Figure 14). The surface of the calcite crystals show dissolution features (Figure 15). Crystalline salts and gypsum crystals are also observed (Figure 16).

\subsection{X-Ray Diffraction (XRD)}

The resulted XRD charts show that the stones are composed mainly of calcite. Minor salts (Halite) and gypsum are observed with quartz (Figure 17).

\subsection{Chemical Analysis by XRF Fluorescence}

The study of Chemical analysis of three limestone samples revealed $\mathrm{CaO}$ is the dominant oxide which ranges from 54.03\% - 55.11\% which reflects that the stones are mainly limestone with calcium carbonate content ranges from 96.11 to $98.37 \%$ (Table 1 ). $\mathrm{SiO}_{2}$ show very minor amounts with an average of $0.58 \%$, 


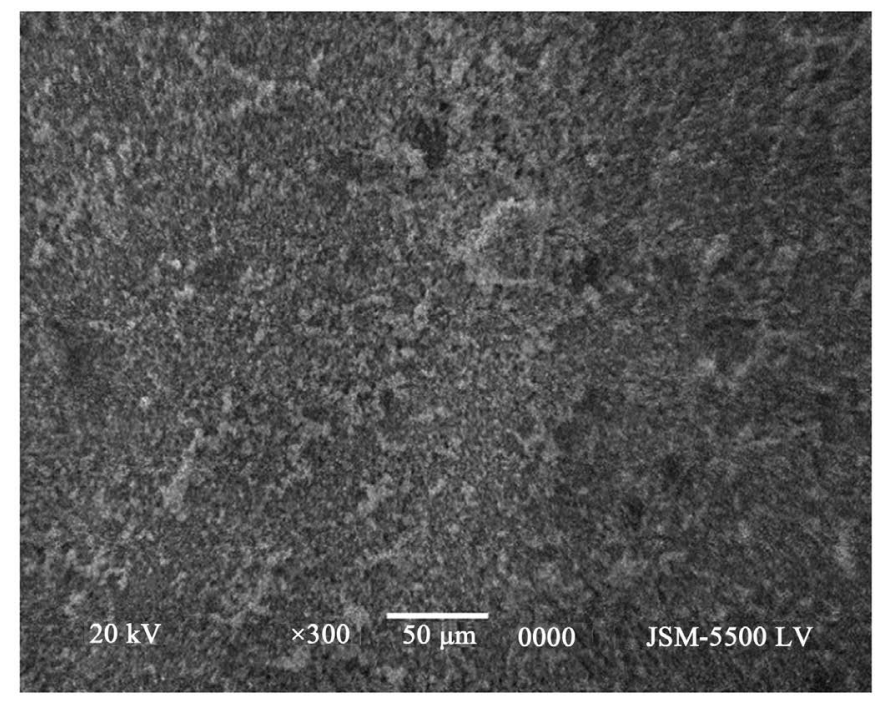

Figure 13. Some micro pores in limestone.

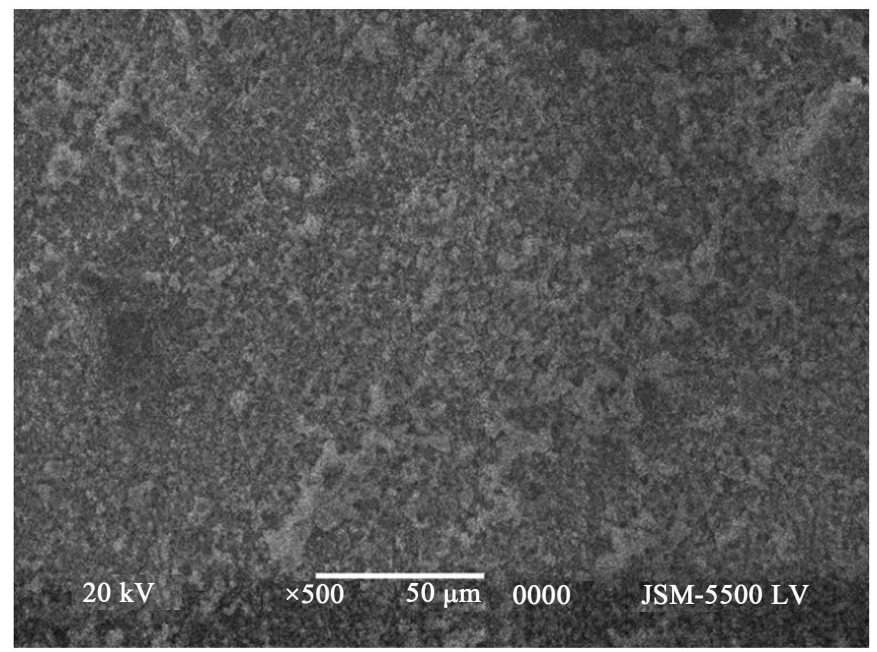

Figure 14. Some fractures result of dissolution.

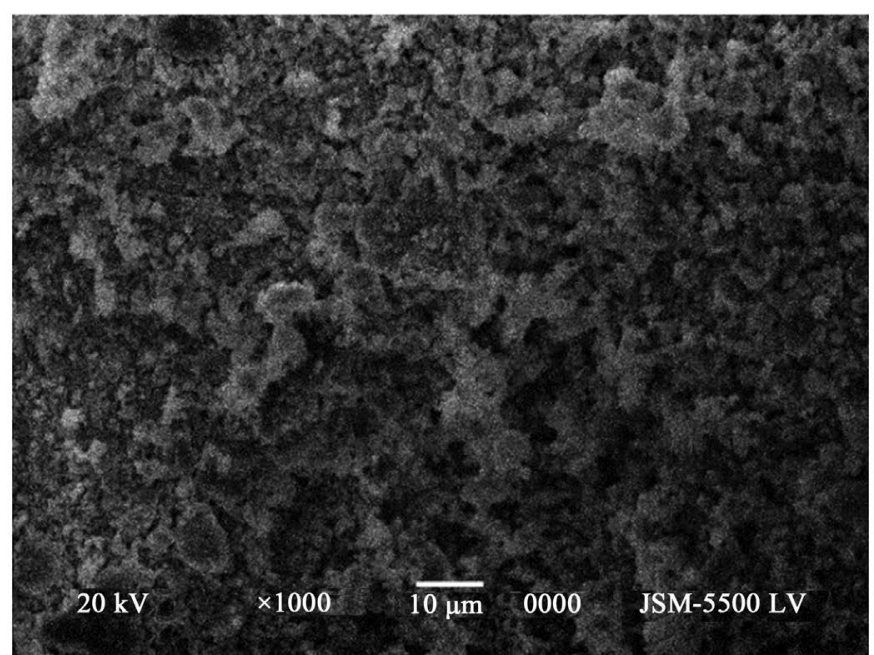

Figure 15. Damage surface of calcite crystals result of dissolution and salts. 


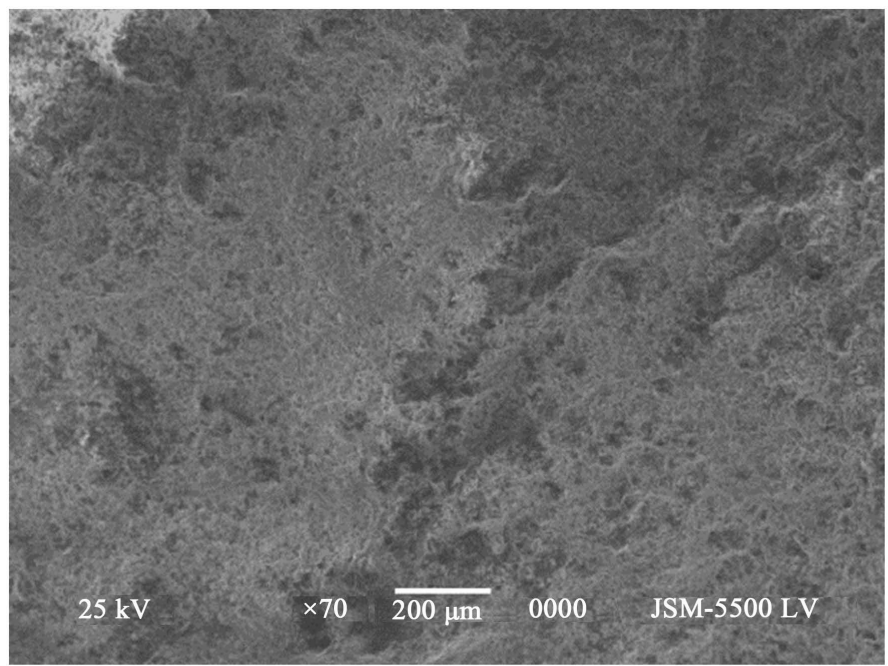

Figure 16. Gypsum and micro cracks in stone.

Table 1. XRF analysis of the studied limestone samples.

\begin{tabular}{|c|c|c|c|}
\hline $\begin{array}{c}\text { Main constituents } \\
\mathrm{Wt} \%\end{array}$ & $\begin{array}{c}\text { White monastery } \\
\text { limestone (1) }\end{array}$ & $\begin{array}{l}\text { White monastery } \\
\text { limestone (2) }\end{array}$ & $\begin{array}{c}\text { White monastery } \\
\text { limestone (3) }\end{array}$ \\
\hline $\mathrm{SiO}_{2}$ & 0.58 & 0.56 & 0.59 \\
\hline $\mathrm{TiO}_{2}$ & 0.02 & 0.01 & 0.01 \\
\hline $\mathrm{AI}_{2} \mathrm{O}_{3}$ & 0.12 & 0.13 & 0.13 \\
\hline $\mathrm{Fe}_{2} \mathrm{O}_{3}$ tot. & 0.07 & 0.08 & 0.08 \\
\hline $\mathrm{MgO}$ & 0.13 & 0.14 & 0.14 \\
\hline $\mathrm{CaO}$ & 54.03 & 55.11 & 54.66 \\
\hline $\mathrm{Na}_{2} \mathrm{O}$ & 0.45 & 0.47 & 0.48 \\
\hline $\mathrm{K}_{2} \mathrm{O}$ & 0.07 & 0.08 & 0.09 \\
\hline $\mathrm{P}_{2} \mathrm{O}_{5}$ & 0.04 & 0.04 & 0.04 \\
\hline $\mathrm{SO}_{3}$ & 0.12 & 0.13 & 0.14 \\
\hline $\mathrm{CI}$ & 0.33 & 0.35 & 0.35 \\
\hline LOI & 44.002 & 42.86 & 43.25 \\
\hline \multicolumn{4}{|l|}{ Total } \\
\hline $\mathrm{MnO}$ & 0.019 & 0.019 & 0.019 \\
\hline $\mathrm{NiO}$ & 0.005 & 0.005 & 0.005 \\
\hline $\mathrm{SrO}$ & 0.014 & 0.014 & 0.014 \\
\hline
\end{tabular}

$\mathrm{Al}_{2} \mathrm{O}_{3}$ shows an average of $0.12 \%$ which could be an indication of the presence of very minor clay minerals. $\mathrm{MgO}$ shows an average of $0.13 \%$ and $\mathrm{Fe}_{2} \mathrm{O}_{3}$ show an average of $(0.07 \%) . \mathrm{SO}_{3}$ shows an average of $0.13 \%$ which indicates the presence of minor gypsum, Gypsum formed when calcium carbonate react with sulfur dioxide ([18] \& [19]). 

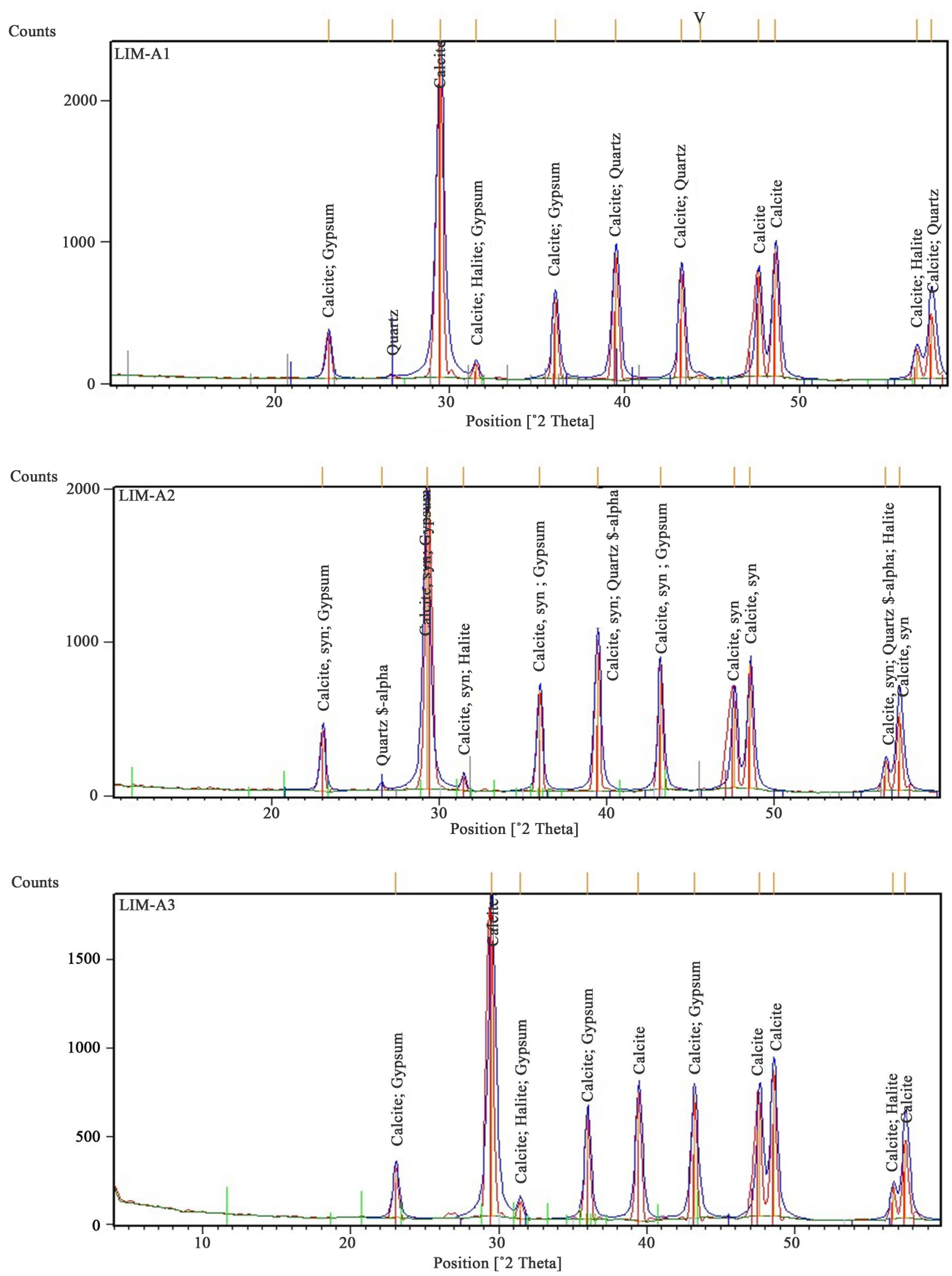

Figure 17. XRD patterns of the studied limestone sample. 


\subsection{Physical and Mechanical Properties}

Table 2 shows the measured physical and mechanical properties of the studied limestone. The average specific gravity of the limestone is $2.06 \mathrm{~g} / \mathrm{cm}^{3}$ which shows that the stone is classified as low density limestone according to the limestone specification ASTM c 568. The average water absorption is $9.26 \%$ is less than the maximum permitted limit of the low density limestone. The average compressive strength value is $16.04 \mathrm{Mpa}$ is higher than the lower limit of the low density limestone (12 Mpa) in the limestone specification ASTM c 568. The average measured flexural strength values of the limestone samples is $3.6 \mathrm{Mpa}$ which is higher than the flexural limit of the low density limestone (1 Mpa) in the ASTM c 568.

\section{1) Stone Restoration and Conservation}

The severity of stone deterioration depends on complex interactions between a number of environmental and intrinsic properties, as well as on the duration of exposure. Based on mineral composition and structures, stone is an extremely complex material-a complexity that is reflected in its behavior against weathering and its response to the natural and the built environment [20].

Active conservation is mainly concerned with doing something directly to the stone itself and the following practices are very frequent:

\section{a) Cleaning}

A lot of techniques and methodologies are available for natural stone cleaning, some techniques are intended for use on large facades, and others are intended for use on finely delicate and carved sculpture. Most of these techniques are mentioned and reviewed by many authors: Ashurst 1994 [21]; Verges-Belmin and Bromblet 2000 [22].

\section{b) Desalination}

In cases where soluble salts are the major factor for stone deterioration, it is worthy to remove these salts. Desalination is usually recovered through various types of poultices, consist mainly of a different types of materials (e.g. clays, sands, as well as paper pulps) [23].

Table 2. Physical and mechanical properties.

\begin{tabular}{ccccc}
\hline Sample No. & $\begin{array}{c}\text { Specific } \\
\text { gravity }\left(\mathrm{g} / \mathrm{cm}^{3}\right)\end{array}$ & $\begin{array}{c}\text { Water } \\
\text { absorption }(\%)\end{array}$ & $\begin{array}{c}\text { Compressive } \\
\text { strength }(\mathrm{MPa})\end{array}$ & $\begin{array}{c}\text { Flexural } \\
\text { strength }(\mathrm{MPa})\end{array}$ \\
\hline 1 & 2.07 & 9.01 & 17.74 & 2.77 \\
2 & 2.07 & 9.27 & 15.66 & 3.56 \\
3 & 2.09 & 8.70 & 14.34 & 3.54 \\
4 & 2.05 & 9.80 & 15.98 & 4.03 \\
6 & 2.02 & 9.47 & 17.44 & 3.40 \\
average & 2.08 & 9.31 & 15.11 & 4.31 \\
\hline
\end{tabular}




\section{c) Consolidation}

Consolidation process is applied when the rock is severely deteriorated by decay. Consolidation processes aim to conserve the stone strength, and maintain its strength as it was originally [24] \& [25], in order to be more resistant for further decay

Most of materials that have been used as stone consolidators are organic polymers. On the other hand, inorganic consolidator materials deserve a particular mention, as their working mechanisms are quite different: slaked lime (calcium hydroxide) and barium hydroxide.

\section{d) Surface Coatings}

Surface coating materials are a bit of a catchall category that include a wide range of materials used as stone protective water repellent, ant-graffiti coatings, emulsion, protective oxalate layers, salt inhibitors, colloidal silica, biocides, bioremediation treatments and sacrificial lime coatings.

\section{e) Penetrating Sealers}

The alkoxysilanes and alkyl alkoxysilanes, also known as "silanes" for short, are the most widely used as stone consolidators especially in the last twenty years [24]. Two main compounds, in particular, have been dominated: methyl trimethoxysilane [MTMOS] and tetra ethoxysilane [TEOS]. The silanes should be hydrolyzed with water to produce silanols, silons are then polymerize through condensation reactions resulting in silicone polymers.

\section{2) Preservation of the Limestone in the White Monastery}

The function of treatment is to reduce the weakness of the stone structure by improving its properties to resist various deterioration factors [26]. They must improve the properties when treating stones, Salt weathering and gypsum pose a significant risk of limestone and causing a big problem in the ways of preservation of cultural heritage [27]. The weathering rates in different climatic conditions are due to the interaction of water molecules with a mineral surface [28] [29] [30]. Sealers are proposed to protect the stone from the effect of water or humidity.

\section{3) Penetrating Sealers}

The stone samples were treated with penetrating sealer of (Aqua Mix). The results of the treatment are shown in Table 3.

Images of the scanning electronic microscope show the extent of the penetration of the material between the granules, and their ability to encapsulate the limestone granules on a regular basis, and the absence of calcification or inappropriate gatherings (Figure 18).

From the table it is shown that the water absorption of the limestone samples (average 9.26\%) is reduced after the treatment with penetrating sealer to $1.22 \%$ which will protect the limestone from the action of the ground water and reduce the possibility of efflorescence formation.

\section{Conclusion and Recommendations of Conservation}

The bulk sample of ancient building stone of White Monastery is composed 

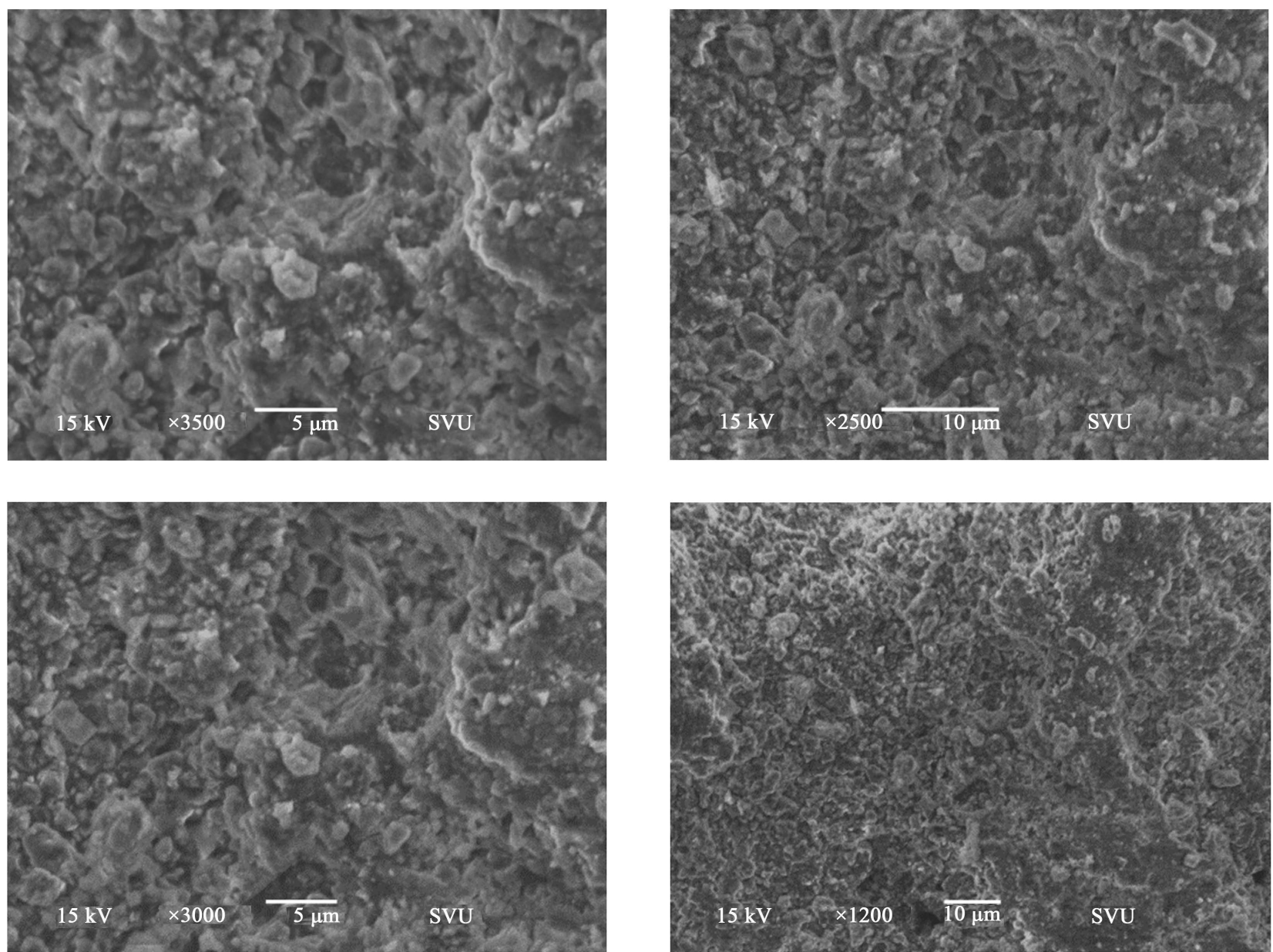

Figure 18. SEM of limestone samples after treatment.

Table 3. Results of water absorption of the limestone before and after treatment with sealer.

\begin{tabular}{ccc}
\hline Sample No. & Water absorption (\%) & Water absorption (\%), after sealing \\
\hline 1 & 9.01 & 1.93 \\
2 & 9.27 & 1.4 \\
3 & 8.70 & 0.78 \\
4 & 9.80 & 1.37 \\
5 & 9.47 & 0.33 \\
6 & 9.31 & 1.52 \\
Average & 9.26 & 1.22 \\
\hline
\end{tabular}

mainly of calcite (87.5\%) with remarkable minor amounts of halite, gypsum and quartz. Crystallization of salts inside the limestone is considered one of the main reasons for the damage, since each different salt degree, with different capacity in absorbing water from the atmosphere, and some salt changes shape as a result of hydration and dehydration. Away from moisture, building stone weathers very slowly. Moisture favors, not only condition for chemical deterioration, but 
also absorb sulphur and carbon dioxide gases, sulphate and carbonate particles from the air. Surface moisture accelerates the rates at which stone deteriorates. The use of penetrating sealers reduced to a great extent of the absorption ability of the limestone and hence will minimize the moisture level that will deteriorate the limestone.

\section{References}

[1] Viaud, G. (1979) Les pelerinagescopts en Egypted'apres les notes du commos, Jacop Muyser. Bibliothequed' Etudes Coptes, Cairo.

[2] Atiya, A. (1991) The Coptic Encyclopedia, Vol.1. MacMillan Reference Library, New York.

[3] Meinardus, O. (1961) Monks and Monasteries of Egyptian Desert. AUC Press, Cairo.

[4] Badawy, A. (1949) L'Artcopte: les influences Egyptiennes d'art copte. Le Caire, Cairo.

[5] Rice, D. (1959) Bazantin Art. Clarendon Press, London.

[6] Benz, E. (1963) The Eastern Orthodox. Aldine Publishing, Chicago.

[7] Galal, A. (1986) The Continuity of Ancient Egyptian Style in Coptic Architecture and Art. PhD dissertation, Cairo University, Cairo.

[8] Vergès-Belmin, V. (2008) Illustrated Glossary on Stone Deterioration Patterns. [Glossaireillustrésur les formesd'altération de la pierre.] ICOMOS and (ISCS) International Scientific Committee for Stone, Paris.

http://international.icomos.org/publications/monuments_and_sites/15/pdf/Monum ents_and_Sites_15_ISCS_Glossary_Stone.pdf

[9] Karpuz, C., Ceylanoğlu, A. and Paşamehmetoğlu, A.G. (1992) An Investigation on the Influence of Depth of Cut and Blasting on Shovel Digging Performance. International Journal of Surface Mining, Reclamation and Environment, 6, 161-167. https://doi.org/10.1080/09208119208944331

[10] Fitzner, B. and Heinrichs, K. (2002) Damage Diagnosis on Stone MonumentsWeathering Forms, Damage Categories and Damage Indices. In: Prikryl, R. and Viles, H.A., Eds., Understanding and Managing Stone Decay, Proceeding of the International Conference "Stone Weathering and Atmospheric Pollution Network (SWAPNET 2001)”, May 7-11 2001, Prachov Rocks, 11-56.

[11] Küçükkaya, A.E. (2004) The Causes of Stones Deterioration and Their Protection Methods. Birsen Publishing House, Istanbul.

[12] Siedel, H., von Plehwe-Leisen, E. and Leisen, H. (2008) Salt Load and Deterioration of Sandstone at the Temple of Angkor Wat, Cambodia/Salzbelastung und Sandsteinschädenan den Tempelanlagen in Angkor Wat. In: Lukasziewicz, J. and Niemcewicz, P., Eds., Proceedings 11th International Congress on Deterioration and Conservation of Stone, 267-274.

[13] Lazzarini, S.G., Miller, G.J. and Zenger, T.R. (2008) Dealing with the Paradox of Embeddedness: The Role of Contracts and Trust in Facilitating Movement of Committed Relationships. Organization Science, 19, 709-728. https://doi.org/10.1287/orsc.1070.0336

[14] Franzmann, S. and Kaiser, A. (2006) Locating Political Parties in Policy Space: A Reanalysis of Party Manifesto Data. Party Politics, 12, 163-188. https://doi.org/10.1177/1354068806061336 
[15] Reed, R.M. (2002) Town Mountain Granites. University of Texas. https://uts.cc.utexas.edu/rmr/tmg.html

[16] Abd-Elkareem, E.A. and Mohamed, R.M. (2017) Microbial Deterioration of Limestone of Sultan Hassan Mosque, Cairo-Egypt and Suggested Treatment. International Journal of Chem Tech Research, 10, 535-552.

[17] Piervittori, R., Salvadori, O. and Isocrono, D. (2004) Literature on Lichens and Biodeterioration of Stonework. Lichenologist, 36, 145-157. https://doi.org/10.1017/S0024282904014136

[18] Efes, Y. and Luckat, S. (1976) Relations between Corrosion of Sandstones and Uptake Rates of Air Pollutants at the Cologne Cathedral. 2nd International Symposium on the Deterioration of Building Stones, Athens, 193-200.

[19] Cezar, T.M. (1998) Calcium Oxalate: A Surface Treatment for Limestone. Journal of Conservation and Museum Studies, 4, 6-10. https://doi.org/10.5334/jcms.4982

[20] Warke, P., Mckinley, J. and Smith, B. (2006) Variable Weathering Response in Sandstone: Factors Controlling Decay Sequences. Earth Surface Processes and Landforms, 31, 715-735. https://doi.org/10.1002/esp.1284

[21] Ashurst, N. (1994) Cleaning Historic Buildings. Vol. 1 and 2, Donhead, London.

[22] Verges-Belmin, V. and Bromblet, P. (2000) Le nettoyage de la pierre. Editions du Patrimoine, Paris, 220-273.

[23] Auras, M. (2008) Poultices and Mortars for Salt Contaminated Masonry and Stone Objects SWBSS.

[24] Snethlage, R., Gruber, V. and Wendler, W. (2008) Transforming Gypsum into Calcium Phosphate: A Better Way to Preserve Lime Paint Layers on Natural Stone. In: Delgado Rodrigued, J. and Mimoso, J.M., Eds., Stone Consolidation in Cultural Heritage Research and Practice: Proceedings of the International Symposium, Lisbon, 6-7 May 2008, 1-14.

[25] Scherer, G. and Wheeler, G. (2009) Silicate Consolidants for Stone. Key Engineering Materials, 391, 1-25. http://www.scientific.net

[26] Gauri, K.L., Gwinn, J.A. and Popli, R.K. (1976) Performance Criteria for Stone Treatment. 2 nd International Symposium on the Deterioration of Building Stones, Athens, 143-151.

[27] Nijland, T. and Van Hees, R. (2009) Salt Decay of Morley Limestone. Heron, 54, 279-289.

[28] Hudec, P. (1978) Rock Weathering on the Molecular Level. Geological Society of America, Engineering Geology Case Histories No. 11, U7-51. https://doi.org/10.1130/Eng-Case-11.47

[29] Hyvert, G. (1978) Weathering and Restoration of Borobudur Temple, Indonesia. Geological Society of America, Engineering Geology Case Histories No. 11, 95-100. https://doi.org/10.1130/Eng-Case-11.95

[30] Keller, W.D. (1978) Progress and Problems in Rock Weathering Related to Stone Decay. Geological Society of America, Engineering Geology Case Histories No. 11, 37-46. 
Submit or recommend next manuscript to SCIRP and we will provide best service for you:

Accepting pre-submission inquiries through Email, Facebook, LinkedIn, Twitter, etc. A wide selection of journals (inclusive of 9 subjects, more than 200 journals)

Providing 24-hour high-quality service

User-friendly online submission system

Fair and swift peer-review system

Efficient typesetting and proofreading procedure

Display of the result of downloads and visits, as well as the number of cited articles Maximum dissemination of your research work

Submit your manuscript at: http://papersubmission.scirp.org/

Or contact ojg@scirp.org 